\title{
Mohamed Amin
}

\section{By Chris A. Paterson, Georgia State University}

"Nothing's impossible. It's all possible if you want it." This the Kenyan cameraman Mohamed Amin told me-a message about journalism he delivered unceasingly to any audience who would hear him In November, Mo Amin was killed in the Comoros Islands plane crash-a brutal irony for a man who had spent a lifetime striving to cover news without becoming a part of it. Amin did more than any other journalist to provide the world with fair and balanced reporting of Africa.

Few people have had as many close brushes with death as Mo Amin, few have been so indestructible; but finally, Mo encountered a situation where he could not maintain that slight element of control that permitted him to escape so many times before. (In Ethiopia a few years back Mo's brush was so close that he lost an arm, and a colleague, but it never slowed him). Africa, and Mo's native Pakistan which he loved and which loved him, are, like the rest of the developing world, too often ignored by a Western media that can only portray peace and routine politics and economics when they happen close to home (that, for international television journalists, is London, New York, and Atlanta). Close to home is easy on news coverage budgets, but the result is an image of developing countries, and the majority of people in the world, in perpetual chaos. Mo Amin, who worked mostly for Reuters Television (formerly Visnews), spent a lifetime fighting, always insisting that no excuse was good enough to avoid a story, and that it was wrong to present this singular and deeply distorted view of a continent. I did not know Mo well, having only met and interviewed him once. But as I complete a book on television news agency coverage of the developing world, I may have a better sense than some of Mo Amin's journalist brethren of the depth of his contribution. He has had much to do with keeping Africa on the international news agenda (though just barely) for most of my lifetime-over three decades.

Mo is best remembered for extraordinary video journalism which motivated rich nations to make a rare generous and personal gift to Africa, and save the lives of millions starving in Africa's Horn in 1984. Mo's intrepid journalism, not the BBC, NBC, or Visnews, were responsible for this story and its effect, though those organizations gladly rode his coattails. What often gets left out of the Mo legend (a legend he-and biographer Brian Tetley, who was killed with Amin-had a hand in promoting) is the vastness of human history that would not have been written had Mo not been there, had Mo not fought his London news agency editors tooth and nail for story after story. Global journalism tends to ignore Africa when the few media giants writing the world's news are not held accountable. Mo waged the fight every day, digging for stories throughout Africa and pushing them under the noses of his news agency bosses. So respected was Mo-holder of the British $\mathrm{OBE}$, of every journalism and humanitarian award, and friend to royals, presidents, and potentates the world over-that editors under intense pressure to find any excuse to refuse the expense of African coverage would have to listen, and often, would have to allow Mo to do what he did best. In the early nineties Mo tried to cover new famine in the Horn, but was mostly ignored, with US military intervention in Somalia being one result. In 1995 he told me of his frustration in trying to cover elections in Africa's most populous, and for the West, strategically important nation, Nigeria. His editors did not want the story unless there were "bodies in the streets." When, he asked, is this same criteria applied to election coverage in Western countries?

Recently though, Amin scored a great triumph by developing with (and for) Reuters, a weekly news program about Africa for African broadcasters; it has been the first commercially successful continent-wide television news project, although most African broadcasters still cannot afford it. The program is one of his greatest legacies, and broadcasters the world over should be encouraged to air it. Editors and program buyers continue to assume Africa is of no interest, that the continent is synonymous only with despair, and that the African Diaspora represents an audience unworthy of cultivation.

Now Mo Amin is silent. A few excellent journalists still represent big media in Africa, but none have the power to challenge, as Mo routinely did, a corporate journalism with little room for Africa. Mo is a hero to me, not just for his magnificent and remarkable photojournalism, but for using his stature for the betterment of the nations and people he loved. Media critics (ASA colleagues among them) will continue the fight, and so too will caring journalists and unsatisfied media consumers everywhere. But will it be enough? I fear none will speak again with the authority of Mo Amin.

\section{Claude Ake}

\section{By Guy Martin, Clark Atlanta University}

It was in the course of a conversation I was having with fellow political scientist Mahmood Mamdani-who recently took up a Chair in African Studies at the University of Cape Town-that I learned of the sudden and untimely death of Claude Ake, one of 142 passengers and crew of the ADC Airlines plane that crashed shortly before landing at Lagos Airport outbound from Port Harcourt on November 7, 1996. Claude was arguably one of the most brilliant, original and prolific of the new generation of African political scientists who emerged to prominence in the seventies. A product of Columbia University-yet firmly grounded in his Ogoni traditional society-he was one of the first scholars to openly challenge the conventional wisdom of Modernization theory which was then the undisputed paradigm in African studies and to propose instead a bold and innovative political economy approach for a better understanding of Africa's chronic economic, political, and social crisis. A kind of intellectual testament, his latest book, Democracy and Development in Africa (Brookings Institution, 1996) is assuredly destined to become a classic.
Not surprisingly, over the last ten years, Claude and I kept bumping into each other at various meetings of African social science organizations in which we were both actively involved, principally the African Association of Political Science (AAPS), and the Council for the Development of Social Science Research in Africa (CODESRIA). Claude's presidency of CODESRIA shall certainly be remembered as one of the most dynamic and innovative in the short life of the organization, which under his inspiring leadership, launched a series of major research networks on social movements, 